\title{
Accounting
}

\section{The role of enterprise risk management on disclosure transparency in the international financial reporting standards period}

\author{
Bisan Almasri ${ }^{a^{*}}$ \\ a Applied Science Private University, Jordan

\section{H R O N I C L E} \\ Article history: \\ Received: January 12, 2021 \\ Received in revised format: \\ April 82021 \\ Accepted: April 14, 2021 \\ Available online: \\ April 15, 2021 \\ Keywords: \\ Enterprise Risk Management \\ International Financial Reporting \\ Standards \\ Disclosure Transparency \\ Firm Incentives
}

\section{A B S T R A C T}

This research empirically investigates the role of the enterprise risk management system implementation level in capturing firm managerial incentives. The system plays an important role in understanding the association between international financial reporting standards and the capital market. Listed firms in the Australian market were used for the period 2000-2010 for this purpose. The study results imply that implementing higher levels of ERM by Australian firms during the mandatory IFRS adoption period does not capture firm incentives in IFRS period. Consequently, these results suggest that the implementation of ERM by Australian firms does not reduce the contractual costs between investors and management, whilst adopting IFRS does. Future research may use other techniques and/or strategies other than ERM, to capture the firm incentives, and as a result, may have economic consequences.

\section{Introduction}

International Financial Reporting Standards (IFRS) as a high-quality standard may not achieve its stated objective of producing high-quality financial reports that serve the needs of stockholders, due to several factors. The need for firm incentives to be transparent is an important factor used to control the capital market effects of adopting IFRS, and there is a clear consensus in the international community that greater transparency is required by organizations, so efforts to strengthen the international financial system must go beyond improving transparency (Australia Treasurer, 1998). Incentives appear to dominate highquality standards as a determinant of the quality of financial reporting (Verrecchia, 2001; Lambert et al., 2007; Leuz \& Verrecchia, 2000; Daske et al., 2013; Lin et al., 2012; Li, 2010; Jeanjean \& Stolowy, 2008). One area of organisational economics that researchers have investigated empirically, the conflict of interest between managers and stockholders (Verrecchia, 2001). In addition, some researchers have argued that incentives appear to be a determinant of the quality of financial reporting (Lin et al., 2012; Li, 2010; Jeanjean \& Stolowy, 2008). Also, internationally accepted standards with respect to transparency, allow market participants to compare disclosure practices against agreed benchmarks of good practice (Australia Treasurer, 1998). Therefore, harmonising incentives rather than standards, is a priority (Jeanjean \& Stolowy, 2008; Daske et al., 2008). Therefore, management without high-quality incentives will find adopting IFRS attractive as a means of false signalling of high-quality reporting.

* Corresponding author.

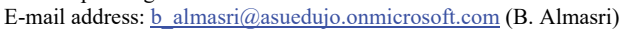


The contractual association between managers and stockholders should not be discussed separately from reporting incentives or managerial incentives (Harris, Johnson, \& Souder, 2013). Agency problems, where managers with high-quality incentives may endeavour to signal stockholders about their transparency incentives (Ball et al., 2003), is another factor to be considered when investigating incentives of firms under IFRS. On the other hand, Coles, et al. (2006); Wright, et al. (2007) found that risktaking strategy is positively associated with incentives given to managers. Furthermore, a new management philosophy for risk management is integral to fair value accounting, to achieve transparent disclosures, fair value accounting and the management of the firm, (Jones \& Luther, 2008; Barlev \& Haddad, 2003). Additionally, it is important to ensure that the incentives are there for information to be used and incorporated in appropriate risk assessments (Australia Treasurer, 1998). The enterprise risk management (ERM) system is a new comprehensive risk management system, rather than the traditional view of risk, in that one of its implementation pillars is the transparency of disclosures (Jensen \& Meckling, 1976; Acharyya \& Johnson, 2006). many guidelines such as COSO framework and ISO 31000, were released to help management adopt suitable risk management systems that are strategically managed (Arena et al., 2010; Beasley et al., 2005; COSO, 2004; Kleffner et al., 2003). ERM implementation may capture managerial incentives, since one of its pillars is the transparency of disclosures, which may indicate that the willingness of management to adopt higher level of ERM reflects an emphasis on transparency. Therefore, the adoption of IFRS alongside ERM, may achieve the objective of IFRS of more transparent disclosures.

\subsection{Research objective}

Based on the researchers' best knowledge, no study has captured managerial incentive factors using the ERM system, when linked to IFRS. This research aims to investigate the role of enterprise risk management implementation level (ERMIL). This will be done by testing the effect of mandatory adoption of IFRS instead of Australian GAAP on firm incentives, and then the incremental value of the ERM system on firm incentives. Furthermore, the research builds on the argument around agency theory and contingency theory, by introducing empirical evidence of ERM, which as a result, may reduce costs of conflict between firm management and stockholders.

\section{Literature review}

AS mentioned in IFRS conceptual framework, transparency is crucial for maintaining qualitative characteristics of financial reporting. Three questions are raised consequently: Does IFRS adoption achieve high reporting quality? Does higher reporting quality increase transparency? Does increasing transparency reflect management incentives to be transparent? For the above questions, Barth et al. (1995) indicated that adopting IFRS as a high-quality standard is not the only factor that improves the quality of accounting information, since law enforcement and reporting incentives are also factors. Ball et al. (2003) also explained that high quality standards are necessary but not a condition for high-quality information. Also, Ball et al. (2006) discussed that reporting quality is largely shaped not by accounting standards alone, but also by economic and political forces. This assumes that adopting IFRS will not alone guarantee a reporting that is of high quality; reporting incentives must be taken into consideration in line with adopting IFRS in order to enhance the reporting quality (Soderstrom \& Sun, 2007; Jeanjean \& Stolowy, 2008). For example, some studies did not find an association between voluntary IFRS adoption and lower earnings management, as one of the concepts of reporting quality (Tendeloo \& Vanstraelen, 2005; Jeanjean \& Stolowy, 2008). Some other studies argued that reporting under GAAP is higher or at least similar quality compared to IFRS, regarding value relevance, earnings management and timely recognition (Lin, Riccardi, \& Wang, 2012; Goodwin, Ahmed, \& Heaney, 2008). Which means that the change in accounting quality may not be attributed to the change of financial reporting system, but to incentives and economic environment. Furthermore, reporting incentives dominate the accounting standards in determining accounting quality (Christensen, Lee, \& Walker, 2015). Thus, firms that have incentives to adopt high-quality standards, will achieve higher quality accounting information than firms that do not have such incentives. Klinsukhon (2016) found that the transparency of the accounting information has a positive effect on the quality of financial reporting. Moreover, some other studies found that transparency is negatively associated with the cost of capital (Barth, Konchitchki, \& Landsman, 2013; Deboskey \& Mogharebi, 2013). On the other line, Barlev and Haddad (2003) focused more specifically on the management perception of their duties within IFRS adoption, especially their requirements of full disclosures and transparency. At this point, the researchers provided explanations about the contribution of fair value accounting to stewardship, agency costs and management efficiency. They also argued that management should take responsibility for achieving the goals of the new fair value accounting via making shareholders' equity the focus of interest. They contributed to the discussion by investigating the value relevance of fair value accounting from the management perspective. Additionally, Cohen et al. (2017) examined how ERM affects the quality of the financial reporting process, internal controls and auditing by interviewing three key players in the reporting process (CFOs, audit committee members and auditors) within 11 companies. They argued that this linkage is critical because the financial reporting adequately depicts the financial status and firm associated risks revealed by ERM. Based on the argument of Adams et al. (2011), the company strategies and risks should be more explicitly and transparently disclosed to investors. In addition, firms should give the initiatives to integrated reporting that incorporates financial and non-financial metrics and their interlinkages. This captures a longer-term perspective and better reflects the firm strategy, as a result, 
enhancing the disclosure of risks. They found that ERM affects the quality of the reporting. Furthermore, Bunyamin and Agustina (2018) discussed the role of risk management on firm value for public companies that have a subsidiary in different countries. Using a linear regression model to analyse the effect of country risk of firm performance, they found a negative effect of risk on return on equity. This result indicates that the parent company can benefit from using country risk as a tool to measure returns. As a result, it indicates the role of using a managerial tools or strategy to manage country risk in order to improve firm value for parent companies.as mentioned by COSO, ERM includes managing country risk rather than the traditional risk management. Shin and Park (2017) provide evidence of the use of ERM by auditors as a tool to manage risk of subsidiaries, and can be used as a guideline by the organizations. Another study by Alviniussen and Jankensgard (2009) designed a study to bring risk management into the financial planning process. They present a quantitative approach to risk management in the nonfinancial firm to evaluate financial distress-probabilities by incorporating ideas related to the concept of the firm's economic capital. They addressed that enterprise risk budgeting makes it possible to assess the firm's expected financial position and overall risk profile, and how this resulted in corporate policy decisions. Additionally, they found that transparency increases the likelihood that management makes decisions with respect to its risk profile, rather than reacting to challenging circumstances. Grody and Hughes (2016) published two papers regarding enterprise risk management. In the first paper they discussed why bankers must view the need for the convergence of finance and risk systems within the reporting framework. In the part two of the paper, they discussed that Basel requirements of risk management by banks help bankers implement controls over risk that are applicable to accounting data to ensure the precision, timelines, comprehensiveness and adaptability of risk reporting. Hence, ERM should not be discussed separately from the management reporting, and, more importantly, from agency theory, since ERM appears to primarily play a monitoring role in their sample companies. Lastly, this study fills the gap by testing the managerial incentives of mandatory IFRS adoption from the perspective of ERM empirically.

\section{The proposed study}

The implication around the economic consequences of IFRS adoption depends on two factors, which are the managerial incentives and legal enforcement. Since ERMIL is expected to capture the managerial incentives to be transparent, the researcher suggests that implementing a higher level of ERM under IFRS period adoption, may achieve higher quality of reporting that is realized by investors. Taken together, the researcher hypothesized the following hypothesis:

Hypothesis 1. Implementing a higher level of ERM under the mandatory adoption of high-quality standards (IFRS) by Australian firms listed in ASX, has a statistically positive influence on firm disclosures transparency.

Method is different from methodology. Thus, methodology is a broader term and refers to more than one set of methods. The method is the hypothetico-deductive methodology (Gaffikin, 2006), or it is the particular choice of methodology. It also refers to the specific analysis techniques and describes the tools that are used to collect data, such as the survey, questionnaire, interview, reports and observation (Bakker, 2018). So, the development of hypothesis, data collection and analysis techniques, are referring to the research method. The study population comprises the Australian market. The research of disclosures transparency around IFRS adoption have received less attention and limited evidence in Australia. Australian listed firms that listed for the period of 2000-2010 in ASX chosen for this purpose, and that can provide the data required for computing the study variables, will be chosen as follows:

\section{Table 1}

The study sample

\begin{tabular}{lrrr}
\hline Number of firms & Firms that do not satisfy the data requirements & Firms that satisfy the data requirements (as mentioned above) & The Sample \\
\hline 2197 & 1859 & 3380 \\
\hline
\end{tabular}

Secondary data is the only source used to collect the study variables and includes financial reports of the Australian firms. The Australian stock exchange website was also used to access the financial reports. For some control variables, the main source was Bloomberg database. Additionally, books and articles related to the topic, and data available online, such as the FASB, IASB and COSO websites were used. The study used the empirical method to answer the research question. Quantitative measures for the period $(2000-2010)$ were collected and calculated from financial reports of the firms and Bloomberg database. Essentially, the sample includes the listed Australian firms, which were split into two groups: pre-IFRS adoption period and post-IFRS adoption period. In particular, the pre-IFRS adoption comprises all sample firms before 2005 in Australia, whilst post-IFRS adoption comprises all sample firms after 2005 in Australia. The date of 2005 is used to control for the period of mandatory IFRS adoption in Australia. The panel-data technique was used to regress each firm-year transparency disclosures on the independent variables. Choosing the period of 2000-2010 is important to address the date of mandatory adoption of IFRS in Australia. This is a sufficient period to address the effect of the transition from Australian GAAP to IFRS, on firm incentives. The sample period is also a sufficient period to capture changes in managerial strategies regarding ERM implementation levels. A multiple regression model was developed to test study hypotheses. This model examined the effect of adopting IFRS on firm 
incentives using the GAAP period as the control sample. It also tested the role of the moderator variable (ERMIL) with regard to the relationship between IFRS adoption and the firm incentives proxy, which indicates the incremental value of ERMIL in relation to increased managerial transparency. The panel-data approach will be used to test the following model:

$\left.T R A N_{I Y}=\alpha_{0}+\alpha_{1}{I F R S A_{I Y}+\alpha_{2} E_{R M I L}+\alpha_{3}\left(I F R S A_{I Y} \times E R M I L\right.}_{I Y}\right)+C O N T R O L S_{I Y}+\varepsilon_{I Y}$

where, (TRAN $\mathrm{T}_{\mathrm{IY}}$ ) is the a proxy of firm incentives; (IFRSA ${ }_{I Y}$ ) is a dummy variable that takes the value of (1) for the IFRS adoption period and $(0)$ otherwise; $\left(E R M I L_{I Y}\right)$ is the enterprise risk management implementation level, which takes a value from 0 to 6; (IFRSA IY $^{*}$ ERMIL $\left.L_{I Y}\right)$ represents the implementation of ERM through GAAB or IFRS periods; Controls include Post-AASB, Return Variability, Leverage, Risk Free Rate, Book to Market Ratio and Forecast Bias; finally, (e $\mathrm{e}_{\mathrm{IY}}$ ) is the error term and for each variable (i) and (y) represent the firm-year observation. Heteroscedasticity assumes that the residuals have equal variances across all levels of predictors. In other words, the error variance is approximately constant. Therefore, if there is heteroscedasticity in the model, it should be removed from the model. For this reason, Breusch-Pagan test (see for example, Montes-Rojas \& Sosa-Escudero, 2011; Vandenbulcke et al., 2011; Kohli \& Jaworski, 1990) were performed for heteroscedasticity (see Table 2) and the test indicates an evidence of heteroscedasticity. For this purpose, the researcher corrected the heteroscedasticity using robust standard error (Stock \& Watson, 2008; Adkisson \& Mohammed, 2014).

Table 2

The results of Breusch-Pagan Test

\begin{tabular}{lc}
\hline Fitted Values of WIN_ABS_Accruals & Value \\
\hline chi2 $(1)$ & 2096.98 \\
Prob $>$ chi2 & 0.0000 \\
\hline
\end{tabular}

Outliers can be defined as an observation considered being different from the remainders (He, Xu, \& Deng, 2003; Maiga et al., 2014). In other words, the case that differs significantly from the overall trend of the data, is considered an outlier (Field, 2009). The researcher examined this problem, and found some outliers in some variables. This problem solved using the Winsorizing techniques, by taking $1 \%$ from top and $1 \%$ from bottom.

\section{Regression results}

Table 3 presents the regression result using the accruals as a proxy measure of transparency.

Table 3

The summary of the regression results using Accruals

\begin{tabular}{|c|c|c|c|}
\hline & 1 & 2 & 3 \\
\hline _CONSTANT & $\begin{array}{l}-7.1382 \\
(-6.23)^{* * *}\end{array}$ & $\begin{array}{l}-7.8154 \\
(-6.58)^{* * *}\end{array}$ & $\begin{array}{c}-7.7706 \\
(-6.75)^{* * *}\end{array}$ \\
\hline IFRSA & $\begin{array}{c}1.1909 \\
(9.75)^{* * *}\end{array}$ & $\begin{array}{c}1.1920 \\
(9.72)^{* * *}\end{array}$ & $\begin{array}{c}1.1070 \\
(3.78)^{* * *}\end{array}$ \\
\hline ERMIL & $\begin{array}{c}0.2372 \\
(2.76)^{* * *}\end{array}$ & $\begin{array}{l}0.2154 \\
(2.47)^{* *}\end{array}$ & $\begin{array}{l}0.1874 \\
(2.07)^{* *}\end{array}$ \\
\hline$F R R S * E R M I L$ & & & $\begin{array}{l}0.0481 \\
(0.30)\end{array}$ \\
\hline ENDO & $\begin{array}{c}-0.6682 \\
(-2.78)^{* * *}\end{array}$ & $\begin{array}{c}-0.6738 \\
(-2.81)^{* * *}\end{array}$ & $\begin{array}{c}-0.6728 \\
(-2.79)^{* * *}\end{array}$ \\
\hline VOLATILITY & $\begin{array}{l}0.0025 \\
(2.38)^{* *}\end{array}$ & $\begin{array}{l}0.0021 \\
(2.09)^{* *}\end{array}$ & $\begin{array}{l}0.0021 \\
(2.10)^{* *}\end{array}$ \\
\hline LEVERAGE & $\begin{array}{c}-0.0015 \\
(-1.12)\end{array}$ & $\begin{array}{c}-0.0015 \\
(-1.13)\end{array}$ & $\begin{array}{c}-0.0015 \\
(-1.10)\end{array}$ \\
\hline$R F R$ & $\begin{array}{c}1.3733 \\
(7.80)^{* * *}\end{array}$ & $\begin{array}{c}1.3643 \\
(7.79)^{* * *}\end{array}$ & $\begin{array}{c}1.3645 \\
(7.78)^{* * *}\end{array}$ \\
\hline BTMR & $\begin{array}{l}0.0326 \\
(1.29)\end{array}$ & $\begin{array}{l}0.0333 \\
(1.31)\end{array}$ & $\begin{array}{l}0.0333 \\
(1.32)\end{array}$ \\
\hline INDUSTRY & No & Yes & Yes \\
\hline R-SQUARED & 0.0364 & 0.0402 & 0.0402 \\
\hline F-STATISTICS & 17.81 & 7.59 & 7.17 \\
\hline P-VALUE & 0.0000 & 0.0000 & 0.0000 \\
\hline $\mathbf{N}$ & 3718 & 3718 & 3718 \\
\hline
\end{tabular}


For the first model, three versions of the model were used. The first one is without the interaction between IFRSA and ERMIL (IFRSA * ERMIL), and without the industry factor. In the second regression test the researcher added the industry factor, and the last regression test includes the interaction as shown in Table 3. The first column of the table shows multiple regression analysis of transparency on IFRS adoption, ERM implementation level and the interaction between these two variables, and finally on the control variables. The results indicate that the estimated model is suitable for the sample data and independent variables do significantly explain the variation of transparency since F-value is 17.81 . Regarding $\mathrm{R}^{2}$, it shows that the model explains only $3 \%$ of changes in transparency. The second column of the table which represents the model with adding the industry factor, F-value is 7.59, which means that the estimated model is suitable for the sample data, and independent variables explain the variation of transparency. But with adding the industry factor to the model, it shows that the percentage of the variation in the outcome that can be explained by the model is only $4 \%$. The third column represents the model including the interaction term and industry factor in the independent variables, shows an F-value of 7.17, which indicates that the estimated model is also suitable for the sample data, and the independent variables explain the variation of transparency. The model also explains about $4 \%$ of changes in the dependent variable. In Table 3, IFRS mandatory adoption found to have a positive and significant effect on transparency, as measured by accruals at 1\% level of significance, where the increase of IFRS adoption by one unit will increase earning management, and as a result, decrease the transparency by approximately $100 \%$ of the unit. ERMIL was found to be positive and has a significant effect on transparency at $1 \%$ level of significance. Thus, increasing the implementation level of ERM increases the earning management, and as a result decreases the transparency of reports by about $23 \%$ of the unit. This explains that adopting a higher level of ERM by the firm management may not signal to stakeholders about high quality reports of the firm The second column in Table 3) provides the results of regression analysis if the industry factor is included in the model. IFRS mandatory adoption is found to be positively associated with transparency. Thus, increasing the mandatory adoption of IFRS increases earning management and as a result, decreases transparency by approximately $100 \%$, and this result is significant at $1 \%$ level of significance. For ERMIL, it has a significantly positive effect on transparency at $1 \%$ level of significance. Thus, the increase in the implementation level of ERM by one unit, leads to an increase in earning management and decrease in transparency by about $21 \%$. The third column in table (3) shows the regression results for the first model including the industry factor and interaction term. The first independent variable, the IFRS mandatory adoption has a positive effect on transparency, it affects transparency by about $100 \%$ at $1 \%$ level of significance.

This study hypotheses that implementing a higher level of ERM under IFRS adoption captures the management incentives to be transparent. Results in Table 3 indicate that implementing ERM by the firm increases transparency by $18 \%$, and this result is significant at $1 \%$ level of significance. This means that implementing a higher level of ERM does not capture management incentives to be more transparent, since earning management increases. But the interaction term that represents the implementation of ERM under the adoption of IFRS, shows that implementing a higher level of ERM under the mandatory adoption of IFRS period, increases transparency by $5 \%$, but this effect is not significant.

\section{Regression of the Model Using Jones Model as a Proxy Measure of Transparency}

The first column of Table 4 shows multiple regression analysis of transparency as measured by Jones model (Hill \& Jones, 1992) on IFRS adoption, ERM implementation level, in addition to the control variables. The results show that the estimated model is suitable for the sample data, and the independent variables significantly explain the variation of transparency with an F-statistic is 47.91 . For $\mathrm{R}^{2}$, it shows that the model explains $12 \%$ of changes in transparency, which indicates a low predictive power of the model using the Modified Jones model as a proxy of transparency. The second column in Table 4 presents the regression analysis of transparency as measured by Jones model on IFRS mandatory adoption, ERMIL, the industry term and control variables. The F- statistic of 23.84 shows that the model is suitable, and the independent variables significantly explain the variation in the dependent variable (transparency). $\mathrm{R}^{2}$ explains $18 \%$ of changes in transparency. In the third column of Table 4 , the results present the regression model using Jones model as a proxy of transparency, and IFRS mandatory adoption, ERMIL, industry factor and the interaction term as independent variables, and the control variables. F-statistic measures how much the model has improved the prediction of the outcome compared to the level of inaccuracy of the model. Thus, the model is suitable since the F-statistic is high (22.54). Also, the model explains $18 \%$ of the variation in the outcome. In the first model that does not include the industry factor and the interaction term (the first column of the table), it shows a positive effect of IFRS mandatory adoption on transparency. Thus, the adoption of IFRS increases earning management and decreases transparency by $98 \%$, at $1 \%$ level of significance. ERMIL results show that implementing a higher level of ERM by the firm management increases transparency by approximately $6 \%$, but this effect is not statistically significant. In the second column in Table 4 , the results indicate that IFRS mandatory adoption has a significant and positive effect on transparency of about $98 \%$ at $1 \%$ level of significance. Regarding ERMIL, an increase in the ERM implementation level by one unit increases transparency by approximately $3 \%$, and this effect is not significant. Finally, the third column shows the model that includes both the interaction term and industry factor. It shows that the IFRS mandatory adoption has a statistically significant strong effect on transparency of $100 \%$ at $1 \%$ level of significance. The same result was obtained when using the accruals as a proxy measure of transparency. ERMIL also has an insignificant positive effect on transparency, thus, increasing the implementation level of ERM by one unit, increases transparency by about 5\% of the unit. Additionally, the interaction term between IFRS and ERM shows a statistically 
1246

insignificant negative effect on transparency of approximately $4 \%$. This result is the same when using accruals as a measure of transparency.

Table 4

Regression Results Using Jones Model

\begin{tabular}{|c|c|c|c|}
\hline Model 1 & 1 & 2 & 3 \\
\hline _CONSTANT & $\begin{array}{c}-7.0370 \\
(-12.85) * * *\end{array}$ & $\begin{array}{c}-7.7541 \\
(-14.28) * * *\end{array}$ & $\begin{array}{c}-7.7886 \\
(-14.5) * * *\end{array}$ \\
\hline IFRSA & $\begin{array}{c}0.9856 \\
(15.77) * * *\end{array}$ & $\begin{array}{c}0.9867 \\
(15.71)^{* * *}\end{array}$ & $\begin{array}{c}1.0522 \\
(8.04) * * *\end{array}$ \\
\hline ERMIL & $\begin{array}{c}0.0574 \\
(1.53)\end{array}$ & $\begin{array}{c}0.0255 \\
(0.70)\end{array}$ & $\begin{array}{r}0.0471 \\
(1.40)\end{array}$ \\
\hline FRRS*ERMIL & & & $\begin{array}{c}-0.0370 \\
(-0.56)\end{array}$ \\
\hline ENDO & $\begin{array}{c}-0.1060 \\
(-1.11)\end{array}$ & $\begin{array}{c}-0.1096 \\
(-1.17)\end{array}$ & $\begin{array}{c}-0.1104 \\
(-1.17)\end{array}$ \\
\hline VOLATILITY & $\begin{array}{c}0.0010 \\
(2.22) * *\end{array}$ & $\begin{array}{c}0.0007 \\
(1.39)\end{array}$ & $\begin{array}{c}0.0006 \\
(1.36)\end{array}$ \\
\hline$L E V E R A G E$ & $\begin{array}{c}0.0002 \\
(0.11)\end{array}$ & $\begin{array}{c}0.0001 \\
(0.11)\end{array}$ & $\begin{array}{c}0.0001 \\
(0.09)\end{array}$ \\
\hline$R F R$ & $\begin{array}{l}1.3320 \\
(15) * * *\end{array}$ & $\begin{array}{c}1.3245 \\
(15.79) * * *\end{array}$ & $\begin{array}{c}1.3243 \\
(15.78)^{* * *}\end{array}$ \\
\hline$B T M R$ & $\begin{array}{c}0.0250 \\
(2.11)^{* *}\end{array}$ & $\begin{array}{l}0.0201 \\
(1.77)^{*}\end{array}$ & $\begin{array}{l}0.0201 \\
(1.77) *\end{array}$ \\
\hline INDUSTRY & No & Yes & Yes \\
\hline$R-S Q U A R E D$ & 0.1243 & 0.1869 & 0.187 \\
\hline$F-S T A T I S T I C S$ & 47.91 & 23.84 & 22.54 \\
\hline$P-V A L U E$ & 0.0000 & 0.0000 & 0.0000 \\
\hline$N$ & 3718 & 3718 & 3718 \\
\hline
\end{tabular}

Regression of the Model Using Modified Jones Model as a Proxy Measure of Transparency

The first column represents the regression results for the first model using Modified Jones Model as a proxy for transparency, excluding the interaction term and industry factor from the model. The estimated model is suitable for sample data, since Fstatistic is 47.44 and the independent variables significantly explain the variation in the dependent variable. Also, the independent variables explain about $12 \%$ of changes in the dependent variable $\left(\mathrm{R}^{2}=0.124\right)$. The results including the industry factor in the model as shown in column 2, indicate that the estimated model is also suitable for sample data and the independent variables do significantly explain the variation in transparency $($ F-statistic $=23.98)$.

Table 5

The summary of the regression results using modified Jones model

\begin{tabular}{|c|c|c|c|}
\hline Model 1 & 1 & 2 & 3 \\
\hline${ }_{-}$CONSTANT & $\begin{array}{c}-7.4640 \\
(-12.91)^{* * *}\end{array}$ & $\begin{array}{c}-8.2233 \\
(-14.36)^{* * *}\end{array}$ & $\begin{array}{c}-8.2485 \\
(-14.63)^{* * *}\end{array}$ \\
\hline IFRSA & $\begin{array}{c}1.0377 \\
(15.66)^{* * *}\end{array}$ & $\begin{array}{c}1.0389 \\
(15.62)^{* * *}\end{array}$ & $\begin{array}{l}1.0866 \\
(7.93)^{* * *}\end{array}$ \\
\hline ERMIL & $\begin{array}{c}0.0610 \\
(1.53)\end{array}$ & $\begin{array}{c}0.0266 \\
(0.69)\end{array}$ & $\begin{array}{c}0.0424 \\
(1.21)\end{array}$ \\
\hline$F R R S * E R M I L$ & & & $\begin{array}{c}-0.0270 \\
(-0.38)\end{array}$ \\
\hline ENDO & $\begin{array}{c}-0.0896 \\
(-0.9)\end{array}$ & $\begin{array}{c}-0.0935 \\
(-0.95)\end{array}$ & $\begin{array}{c}-0.0941 \\
(-0.96)\end{array}$ \\
\hline VOLATILITY & $\begin{array}{l}0.0010 \\
(2.18)^{* *}\end{array}$ & $\begin{array}{c}0.0006 \\
(1.3)\end{array}$ & $\begin{array}{c}0.0006 \\
(1.29)\end{array}$ \\
\hline LEVERAGE & $\begin{array}{c}-0.0001 \\
(-0.01)\end{array}$ & $\begin{array}{c}-0.0000 \\
(-0.01)\end{array}$ & $\begin{array}{c}-0.0000 \\
(-0.03)\end{array}$ \\
\hline$R F R$ & $\begin{array}{c}1.4048 \\
(15.08)^{* * *}\end{array}$ & $\begin{array}{c}1.3964 \\
(15.91)^{* * *}\end{array}$ & $\begin{array}{c}1.3963 \\
(15.9)^{* * *}\end{array}$ \\
\hline BTMR & $\begin{array}{l}0.0315 \\
(2.4)^{* *}\end{array}$ & $\begin{array}{l}0.0262 \\
(2.1)^{* *}\end{array}$ & $\begin{array}{l}0.0262 \\
(2.09)^{* *}\end{array}$ \\
\hline INDUSTRY & No & Yes & Yes \\
\hline R-SQUARED & 0.124 & 0.1905 & 0.1905 \\
\hline F-STATISTICS & 47.44 & 23.98 & 22.72 \\
\hline P-VALUE & 0.0000 & 0.0000 & 0.0000 \\
\hline $\mathbf{N}$ & 3718 & 3718 & 3718 \\
\hline
\end{tabular}


$\mathrm{R}^{2}$ shows that the independent variables are explaining $19 \%$ of changes in the dependent variable. Additionally, when including the industry factor and the interaction term to the model as shown in column 3 , the results also indicate that the model is suitable and independent variables do significantly explain the variation in dependent variable (F-statistic=22.72). The independent variables explain 19\% of changes in the dependent variable. The results of IFRS mandatory adoption show that it has a strong statistically significant positive effect on transparency in the three columns. This means that the adoption of IFRS by the firm management, increases earning management and decreases transparency by $100 \%$ at $1 \%$ level of significance for the three columns. Furthermore, ERMIL shows a positive statistically significant effect that ranges between $2 \%$ and $6 \%$ in the three columns.

\section{Discussion of findings}

Before discussing the study results, it is important to negotiate the Australian context case around IFRS and ERM. IFRS has been imposed to be adopted by Australian firms since 2005, the mandatory adoption of IFRS in Australia resulting in better accounting quality than previously generally accepted Australian accounting principles, which as a result reduces earnings management (Chua, Cheong, \& Gould, 2012). In the same line, the complex environmental risk in Australia and the need for corporate governance following the collapse of large Australian firms, increased the attention by Australian firms to adopt ERM systems, and increased the emphasis of regulatory bodies to offer guidelines and principles for ERM in Australia. Many results can be concluded from this study. Firstly, this study provided evidence of the role of IFRS adoption period on transparency using three measures of transparency. IFRS mandatory adoption is found to be positively associated with earning management, and as a result decreases transparency. This result is not in line with the research hypothesis, since this study expects no effect of the adoption of IFRS on transparency. The reason for this expectation is that the harmonization of standards does not lead to the harmonization of incentives to be transparent, and management may find it attractive to adopt IFRS for false signalling of high quality reporting. The study provides evidence of the role of ERM on firm incentives to be transparent, under the IFRS period. The results indicate that ERMIL has a positive effect on transparency in IFRS period for Australian firms, in the case of using the accruals as a proxy measure of transparency (the first model), but this is not statistically significant. Although it provides evidence of a negative effect of ERMIL in IFRS period for Australian firms in the case of using the Jones Model and the Modified Jones Model as proxy measures for transparency (the second and third models), this effect is also not statistically significant. The researcher expected a positive effect of ERMIL on transparency around the IFRS adoption period, which means that implementing a higher level of ERM by Australian firms in the IFRS period, leads to an increase in disclosure transparency. The point of view in this expectation is that the transparency problem requires an action or procedure and a selection of appropriate governance mechanism to capture incentives, and risk-taking strategy is positively associated with incentives given to managers (Coles, Daniel, \& Naveen, 2006; Wright, Kroll, Krug, \& Pettus, 2007). Furthermore, the new management philosophy for risk management is an integral to fair value to achieve transparent disclosures (Jones \& Luther, 2008; Barlev \& Haddad, 2003). Additionally, one of the ERM pillars is the disclosure transparency (Acharyya \& Johnson, 2006). Also, academic literature supports a strong link between ERM and financial reporting process (Cohen et al., 2017), which consequently justify implementing higher levels of ERM as an important factor that may play a role in the association between adopting IFRS and the capital market. Thus, the adoption of ERM by the firm management and disclosing it through the financial reports, may reflect the management incentives to be transparent in its disclosures, which potentially captures incentives. Thus, it is expected that implementing a higher level of ERM under IFRS adoption period is positively associated with more incentives to be transparent. Although, previous research found a positive effect of ERM on transparency (see for example; Donald \& Christopher 2018). Many explanations can be concluded for these results. Firstly, investors may not react to the implementation of ERM as a signal point of increased transparency, which can be justified as a poor knowledge of ERM systems by investors. Secondly, since the ERM system is a new paradigm system and little known about the application of it by the management, so Australian firms may adopt ERM incorrectly or insufficiently, especially through disclosures, and as a result, they do not get the expected benefits from the adoption. For example; Ahmad et al., (2014) indicates that the majority of the Australian firms not only extensively implement ERM, but also extensively embed ERM into their corporate strategic processes.

\section{Conclusion}

IFRS is found to be positively associated with transparency for the three models. Although, ERMIL under IFRS period is found to have a not statistically significant positive effect (in the case of using the accruals), and negative effect on transparency (in the case of using Jones and Modified Jones Model). These results support that the adoption of ERM under IFRS period by the Australian firms does not reflect their orientation toward more transparent disclosures. Also, these results offer that the implementation of ERM by Australian firms does not reduce the contractual costs between investors and management, whilst adopting IFRS do. 


\section{Acknowledgement}

The author is grateful to the Applied Science University and deeply appreciates its support both on financial, material and colleagues' support. At various times, the author received helpful discussions with Dr Eswaran Velayutham and the author appreciates his support.

\section{References}

Acharyya, M., \& Johnson, J. (2006). Investigating the Development of Enterprise Risk Management in the Insurance Industry: An Empirical Study of Four Major European Insurers. The Geneva Papers on Risk and Insurance, special issue July, 55-80.

Adams, S., \& Simnett, R. (2011). Integrated Reporting: An opportunity for Australia's not-for-profit sector. Australian Accounting Review, 21(3), 292-301.Adkisson, R. V., \& Mohammed, M. (2014). Tax structure and state economic growth during the Great Recession. The Social Science Journal, 51(1), 79-89.

Ahmad, S., Ng, C., \& McManus, L. (2014). Enterprise risk management (ERM) implementation: some empirical evidence from large Australian companies. Procedia-Social and Behavioral Sciences, 164, 541-547.

Arena, M., Arnaboldi, M., \& Azzone, G. (2010). The organizational dynamics of enterprise risk management. Accounting, Organizations and Society, 35(7), 659-675.

Australia Treasurer. (1998). The Task Force on International Financial Reform. Canberra: Commonwealth of Australia.

Australian Stock Exchange. (2016). ASX. Retrieved 9 15, 2016, from https://www.asx.com.au/regulation/rules-guidance-notesand-waivers.htm

Bakker, J. (2018, 4 27). Methods. Retrieved 12 6, 2018, from https://doi.org/10.1002/9781405165518.wbeosm087.pub2

Ball, R., Robin, A., \& Shuang, W. J. (2003). Incentives versus standards: properties of accounting income in four East Asian countries. Journal of Accounting and Economics, 36(1-3), 235-270.

Barlev, B., \& Haddad, J. R. (2003). fair value accounting and the management of the firm. Critical Perspectives on Accounting, 14(4), 383-415.

Barth, M., Konchitchki, Y., \& Landsman, W. (2013). Cost of capital and earnings transparency. Journal of Accounting and Economics, 55(2-3), 206-224.

Beasley, M., Clune, R., \& Hermanson, D. (2005). Enterprise Risk management: An empirical analysis of factors associated with the extent of implementation. Journal of Accounting and Public Policy, 24(6), 521-531.

Bushman, R. M., \& Smith, A. J. (2003). Transparency, Financial Accounting Information, and Corporate Governance. Economic Policy Review, 9(1), 65-87.

Christensen, H., Lee, E., \& Walker, M. (2015). Incentives or standards: What determines accounting quality changes around IFRS adoption? European Accounting Review, 24(1), 31-61.

Chua, Y., Cheong, C., \& Gould, G. (2012). The Impact of Mandatory IFRS Adoption on Accounting Quality: Evidence from Australia. Journal of International Accounting Research, 11(1), 119-146.

Cohen, J., Krishnamoopthy, G., \& Wright, A. (2017). Enterprise risk management and the financial reporting process: The experiences of audit committee members, CFOs and external auditions. Contemporary Accounting Research , 34(2), 11781209.

Coles, J., Daniel, V., \& Naveen, L. (2006). Managerial incentives and risk-taking. Journal of Financial Economics, 79(2), 431468.

COSO. (2004). Enterprise Risk Management- Integrated Framework. Committee of Sponsoring Organizations.

Daske, H., Hail, L., Leuz, C., \& Verdi, R. (2013). Adopting a Label: Heterogeneity in the Economic Consequences Around IAS/IFRS Adoptions. Journal of Accounting Research, 51(3), 495-547.

Daske, H., Hail, L., Leuz, C., \& Verdi, R. S. (2008). Mandatory IFRS Reporting Around the World: Early Evidence on the Economic Consequences. Journal of Accounting Research, 46(5), 1085-1142.

Deboskey, D., \& Mogharebi, N. (2013). A Study on Effect of Information Assymmetry on Earning Management: Evidence from Tehran Stock Exchange. Management Letter Science, 3(2), 2161-2166.

Eisenhardt, K. M. (1989). Agency Theory: An Assessment and Review. The Academy of Management Review, 14(1), 57-74.

Fama, E. F. (1980). Agency Problems and the Theory of the Firm. Journal of Political Economy, 88(2), $288-307$.

FASB. (2018). IFRS Conceptual Framework. FASB.

Field, A. (2009). Discovering statistics using SPSS (Third Edition ed.). London: Sage publications.

Gaffikin, M. (2006). The Critique of Accounting Theory. university of Wollongong, working paper.

Goodwin, J., Ahmed, K., \& Heaney, R. (2008). The effects of international financial reporting standards on the accounts and accounting quality of Australian firms: A retrospective study. Journal of Contemporary Accounting and Economics, 4(2), 89-119.

Hail, L., \& Leuz, C. (2007). Capital market effects on mandatory IFRS reporting in the EU: Empirical evidence. AFM.

Harris, J., Johnson, S., \& Souder, D. (2013). Model-theoretic knowledge accumulation: The case of agency theory and incentive alignment. Academy of Management Review, 39(3), 424-454. 
He, Z., Xu, X., \& Deng, S. (2003). Discovering cluster-based local outliers. Pattern Recognition Letters, 24(9), 1641-1650.

Hill, C., \& Jones, T. (1992). Stockholder-agency theory. Journal of Management Studies, 29(2), 131-154.

Jeanjean, T., \& Stolowy, H. (2008). Do accounting standards matter? An exploratory analysis of earnings management before and after IFRS adoption. Journal of Accounting and Public Policy, 27(6), 480-494.

Jensen, M. C., \& Meckling, W. H. (1976). Theory of the firm: Managerial behavior, agency costs and ownership structure. Journal of Financial Economics, 3(4), 305-360.

Jones, C., \& Luther, R. (2008). Anticipating the impact of IFRS on the management of German manufacturing companies: some observations from a British perspective. Accounting in Europe, 2(1), 165-193.

Kleffner, A., Lee, R., \& McGannon, B. (2003). The effect of corporate governance on the use of enterprise risk management evidence from Canada. Risk Management and Insurance Review, 45(2), 53-73.

Kohli, A. K., \& Jaworski, B. J. (1990). Market Orientation: The Construct, Research Propositions, and Managerial Implications. Journal of Marketing, 54(2), 1-18.

Lambert, R. A., Leuz, C., \& Verrecchia, R. E. (2007). Accounting Information, Disclosure, and the Cost of Capital. Journal of Accounting Research, 45(2), 385-420.

Leuz, C., \& Verrecchia, R. E. (2000). The Economic Consequences of Increased Disclosure. Journal of Accounting Research, $38(1), 91-124$.

Li, J., Mangena, M., \& Pike, R. (2012). The effect of audit committee characteristics on intellectual capital disclosure. The British Accounting Review, 44(2), 98-110.

Li, S. (2010). Does mandatory adoption of international financial reporting standards in the european union reduce the cost of equity capital? The Accounting Review , 85(2), 607-636.

Lin, S., Riccardi, W., \& Wang, C. (2012). Does accounting quality change following a switch from U.S.GAAP to IFRS? Evidence from Germany. Journal of Accounting Public Policy, 31(6), 641-657.

Maiga, A., Nilsson, A., \& Jacobs, F. (2014). Assessing the interaction effect of cost control systems and information technology integration on manufacturing plant financial performance. The British Accounting Review, 46(1), 77-90.

Soderstrom, N., \& Sun, K. (2007). IFRS Adoption and Accounting Quality: A Review. European Accounting Review, 16(4), 675-702.

Stock, J., \& Watson, M. (2008). Heteroskedasticity-Robust Standard Errors for Fixed Effects Panel Data Regression. Econometrica Journal of the Econometric Society, 76(1), 155-174.

Tendeloo, B. v., \& Vanstraelen, A. (2005). Earnings management under German GAAP versus IFRS. European Accounting Review, 14(1), 155-180.

Verrecchia, R. E. (2001). Essays on disclosure. Journal of Accounting and Economics, 32(1-3), 97-180.

Wright, B., Kroll, M., Krug, J., \& Pettus, M. (2007). Infuences of top management team incentives on firm risk taking. Strategic Management Journal, 28(1), 81-89. 

under the terms and conditions of the Creative Commons Attribution (CC-BY) license (http://creativecommons.org/licenses/by/4.0/). 